\section{VI \\ VERSITA}

Folia Oeconomica Stetinensia

DOI: 10.2478/v10031-011-0017-y

\section{us WNIELZ}

Wydzial Nauk Ekonomicznych i Zarządzania Uniwersytetu Szczecínskiego

\title{
PROCESS OF THE ECONOMIC INTEGRATION OF CHINA WITH ASEAN \\ COUNTRIES. AN OVERVIEW
}

Bogusława Skulska, Prof.

Department of International Economic Relations

Faculty of Economic Science

Wroclaw University of Economics

e-mail: boguslawa.skulska@ue.wroc.pl

Received 16 May 2011, Accepted 18 July 2011

\begin{abstract}
China occupies an important economic position in Eastern Asia, accounting for circa $60 \%$ of trade turnover and capital flows in the region. Based on the regional production network in Eastern Asia, the Chinese economy might constitute an integral part of the regional market. China is interested in a liberal, secure and stable regional market which promotes the adoption of an active role of a participant and promoter of regional trade agreements (RTA) by China, i.e. the free trade agreement China-ASEAN, proposed trilateral free trade agreement of South-Eastern Asia, or EAFTA. China is also interested in participating in and promoting regional monetary and financial cooperation, for example as part of the Chiang Mai Initiative and the development of the regional capital market. The Chinese concept of regionalism is complex due to the diversity of the neighbouring geographic areas. Despite the attachment of China to the ASEAN+3 variant, this country is relatively flexible in its approach to the form and nature of its own participation in multi-dimensional integrations structures, i.e. $\mathrm{EAS}^{1}$. At the same time China has made effort for developing institution outside the regional, i.e. for example SOC, potential security system for the North-Eastern Asia based on Hexalateral Talks.
\end{abstract}

Keywords: economic integration in the East Asia, China's economic cooperation, ASEAN.

JEL classification: F15, F55. 


\section{Introduction}

The observations of the contemporary world prove that we are in a very important and probably a break-through period of development, and we witness a new world order being formed. Despite the position of the leader in the international system still being kept by the United States, the existing triangle, called the Triad - USA, EU and Japan - has to be transformed into a polygon taking into account at least the economies of China and India.

The economic and political ties and integration processes occurring between the Asian countries are very interesting and run with dynamics which cannot be encountered on other continents. At the same time they are characterised by huge diversity, which makes them even more noteworthy.

The subject of this paper is process of economic integration of China with ASEAN, which is being shaped, as potential pretenders for the role of future leaders of global economy. Obviously, this will only be an overview of the topic, an indication of the most important threads characterising the problem.

\section{Reasons for creating regional trade agreements in Eastern Asia}

Nesaduri indicates the flexibility as the main reason for the popularity of bilateralism in Eastern $\mathrm{Asia}^{2}$. The negotiating parties may either retain large autonomy of national policies or intensify the cooperation even beyond the framework specified by WTO. Feng Lu notices that this process will assume two stages: currently a network of bilateral free trade agreements (FTA) is being established in the region, and in future the individual agreements will be probably incorporated into a broader regional structure (large free trade area) ${ }^{3}$. It stands in clear contrast to the integration processes which occurred in North America and Europe, where they were mainly inspired by a strong economic (France and Germany in European Union) or political centre (domination of USA in NAFTA).

The number of the undertaken bilateral initiatives, although pleases the advocates of trade liberalisation, involves a risk of the so-called spaghetti bowl effect ${ }^{4}$. It is necessary to work out methods for ensuring consistency of individual agreements so that the regional cooperation is not reduced to a chaotic tangle of differing regulations. However, this is not the case of creating an institutional superstructure which could waste the benefits resulting from bilateralism, but of creating rules for constructing individual agreements which ensure transparency and comprehensibility of procedures. 
Table 1 . RTA initiatives undertaken by China in 21 . century

\begin{tabular}{|c|c|c|c|}
\hline Country & $\begin{array}{l}\text { Progress stage } \\
\text { (initiated in) }\end{array}$ & $\begin{array}{c}\text { Type of } \\
\text { agreement }\end{array}$ & Fields regulated by agreement \\
\hline APTA & $\begin{array}{l}\text { Implementation (1975; } 2001 \\
\text { - accession of China) }\end{array}$ & PTA & Trade in goods (customs duty preferences) \\
\hline ASEAN & Implementation (2002) & FTA & Trade in goods, services, investment \\
\hline Pakistan & Implementation (2006) & FTA & Trade in goods, services \\
\hline Chile & Implementation (2005) & FTA & $\begin{array}{l}\text { Trade in goods, services, culture, education, } \\
\text { science and technology }\end{array}$ \\
\hline New Zealand & Implementation (2008) & FTA & Trade in goods, services, investment \\
\hline Singapore & Implementation (2008) & FTA & Trade in goods, services \\
\hline Peru & Implementation (2009) & FTA & $\begin{array}{l}\text { Trade in goods, services, combating } \\
\text { protectionism }\end{array}$ \\
\hline Hong Kong & Implementation (2003) & FTA & $\begin{array}{l}\text { Trade in goods, services, institutional } \\
\text { cooperation }\end{array}$ \\
\hline Macau & Implementation (2003) & FTA & $\begin{array}{l}\text { Trade in goods, services, institutional } \\
\text { cooperation }\end{array}$ \\
\hline Costa Rica & Implementation (2010) & FTA & Trade in goods, services \\
\hline GCC & Negotiations (2004) & FTA & Trade in goods, services \\
\hline Australia & Negotiations (2005) & FTA & $\begin{array}{l}\text { Trade in goods, services, investment, } \\
\text { liberalisation of global trade }\end{array}$ \\
\hline Iceland & Negotiations (2007) & FTA & Trade in goods, services \\
\hline Norway & Negotiations (2008) & FTA & $\begin{array}{l}\text { Trade in goods, services, promoting } \\
\text { economic growth and improving life } \\
\text { standard }\end{array}$ \\
\hline SACU & Negotiations (2004) & FTA & Trade in goods, services \\
\hline India & Feasibility study (2003) & RTA & $\begin{array}{l}\text { Trade in goods, services, financial } \\
\text { cooperation }\end{array}$ \\
\hline $\begin{array}{l}\text { Republic of } \\
\text { Korea }\end{array}$ & Feasibility study (2004) & FTA & $\begin{array}{l}\text { Trade in goods, services, investment, } \\
\text { promoting cooperation for common growth }\end{array}$ \\
\hline $\begin{array}{l}\text { Japan, Republic } \\
\text { of Korea }\end{array}$ & Feasibility study (2010) & FTA & Trade in goods, economic cooperation \\
\hline Hong Kong & Implementation (2004) & CEPA & Trade in goods, services \\
\hline Macau & Implementation (2003) & CEPA & Trade in goods, services \\
\hline Taiwan & Implementation (2010) & ECFA & Trade in goods, services \\
\hline
\end{tabular}

PTA - Preferential Trade Agreement

FTA - Free Trade Agreement

RTA - Regional Trade Agreement

CEPA - Closer Economic Partnership Agreement

ECFA - Economic Cooperation Framework Agreement

APTA - Asia-Pacific Trade Agreement

GCC - Gulf Cooperation Council: Bahrain, Kuwait, Oman, United Arab Emirates

SACU - Southern African Customs Union: Republic of South Africa, Botswana, Lesotho, Namibia, Swaziland

Source: own work based on: http://fta.mofcom.gov.cn/; http://www.wto.org/; http://www.bilaterals.org/. 
Since the beginning of the 21. century China has attempted to strengthen its economic and political position in Eastern Asia also by concluding regional trade agreements, RTAs. Since the majority of RTAs are bilateral free trade agreements, FTAs, bilateralism may be indicated as the currently prevailing method of shaping international trade policy by China, and also by other countries located in the Eastern Asia region ${ }^{5}$. The indicated regularity is confirmed by the date presented in Table 1 .

\section{China - ASEAN Free Trade Area}

\subsection{Creation process}

The Chinese concept of CAFTA was created in 1995. At that time Thailand for the first time proposed a special economic zone (SEZ), similar to FTA, covering the southern provinces of China. Since then, in particular since the beginning of 1997, Chinese scholars have proposed various variants of special economic zones along the Chinese coast, Jangcy and Pearl rivers, providing the participation of Japan, South Korea, North Korea (Turmen river economic zone), Russia, ASEAN, Taiwan and Hong Kong. The concept of this type of SEZ differed, however, from the earlier special economic zones created by China in late 1970's and early 1980's, just before the economic reform.

An open pressure was made by Beijing on the establishment of a free trade zone covering China and all ten ASEAN countries during the ASEAN $+3^{6}$ summit in November 2000. Then the Chinese prime minister Zhu Rongji stated that: "in longer term China and ASEAN countries may further develop free trade relations" " He also suggested creating an expert group under the aegis of the Common Committee China - ASEAN for economic and trade cooperation for the purposes of preparing a feasibility study of FTA.

During the ASEAN - China summit in November 2001 prime minister Zhu submitted an official proposal concerning the establishment of a free trade area China - ASEAN (CAFTA) in a perspective of ten years. China proposed opening its market in a part of the key sectors for ASEAN countries within five years. At the same time China guaranteed special preference rates for selected goods from the least developed ASEAN countries, i.e. Cambodia, Laos and Myanmar.

ASEAN accepted that proposal, at the same time initiating a series of meetings with China regarding CAFTA. During the ASEAN - China summit in Cambodia in November 2002, the Framework Agreement on Comprehensive Economic Co-Operation ASEAN - China was declared, which is a legal instrument for managing the future cooperation between the 
parties in the economic dimension. This agreement embraces cooperation regarding goods, services, investment and other related fields. The formulated FTA goals indicated mechanisms of special treatment of new member states of ASEAN, Laos, Cambodia, Myanmar and Vietnam, permitting them in the perspective of five years joining the free trade area. China bestowed the status of specially privileged countries on the three ASEAN members which do not belong to WTO - Vietnam, Laos and Cambodia.

Formal talks concerning CAFTA by China and six ASEAN founder countries - Brunei, Indonesia, Malaysia, Philippines, Singapore and Thailand finished in 2010, and Cambodia, Laos, Myanmar and Vietnam are scheduled to join the area in 2015. The scheme providing a reduction of customs duty rates for 600 agriculture products, including livestock, meat, fish, dairy products, other animal products, trees and vegetable, fruit and nuts, would be launched immediately.

\subsection{CAFTA model}

Analysts associated with ASEAN pointed out that the difficulty in creating CAFTA resulted not only from a huge difference in the economic and social growth levels between ASEAN countries but also from the lack of a leading centre similar to the Germany - France axis in EU or the role the United States in the North American Free Trade Agreement (NAFTA). However, since the CAFTA agreement was concluded, Chinese scholars and politicians have begun seeking an optimum form of operation for this group. The following CAFTA variants have been proposed ${ }^{8}$ :

- “rongru xing" (joining): China joins ASEAN Free Trade Area (AFTA);

- "pinghua qidong" (introducing): China gradually opens its market for ASEAN;

- "xianyi hounan" (from the simplest to the most difficult): China creates a free trade zone with more advanced economies, i.e. Singapore and Malaysia as a strong and stable "core" before incorporating others.

- "you dian dao mian" (from detail to whole): CAFTA should begin its activity from easier industries/products before covering all of them.

- "ciquyu tuijin" (from subregion to full territory): CAFTA could begin its operation from the subregional cooperation level, with use of the Mekong Subregion model, before covering the rest of the territory.

- "yanhai youxian" (priority for coastal areas): CAFTA may initially constitute a forum of cooperation of Chinese coastal areas, including Hong Kong, Macau and maritime ASEAN countries. 
- "bianmao qieru" (initially cross-border trade): Chinese scholars espouse the use of border areas between Vietnam, Laos and Myanmar as experimental CAFTA regions.

- "bian zou bian chang" (education through practice): CAFTA should evolve gradually, step by step, deriving experience from practice.

As a challenge for CAFTA, many proposed going beyond the field of trade and reduction of customs duty rates in the direction of the services (including financial services), science and technology (including information technology), agriculture, tourism and transport (including aviation), electrical power, security and combating cross-border crime (including drug dealing) and regional cooperation (i.e. as part of the Mekong subregion, or the construction of the Chinese South-Western International Corridor via Yunnan).

The China - ASEAN Free Trade Area began its activity as of 1 January 2010 and is the largest FTA in terms of population and the third largest in terms of nominal GDP in the world 9 .

\section{Economic ties between China and ASEAN countries}

The "policy of a good neighbour" is the primary premise of the Chinese diplomacy oriented on strengthening the relationships with the Eastern Asian neighbours. This, in turn, promotes forming a long-term perspective of peaceful co-existence necessary for the development and upgrade of China. Regional cooperation which brings the neighbouring countries closer as a community shall serve both the economic and the political interests of China.

In order to demonstrate the economic ties of China and ASEAN countries, and their economic effects, above all the traditional, the most synthetic measures of the country's power will be used, such as the size of the territory, population, economic potential treated as the core factor. They will be complemented by appraisal criteria specific only or above all for the PRC. That country, regardless of how it is appraised, is an exceptional player on the world stage in many aspects.

Table 2. Population, area and GDP per capita of China against the primary players of the global and Eastern Asia economies (data as of 2008)

\begin{tabular}{|l|c|c|c|c|}
\hline Country & $\begin{array}{c}\text { Population } \\
\text { (thousand) }\end{array}$ & $\begin{array}{l}\text { Area } \\
\left(\mathrm{km}^{2}\right)\end{array}$ & $\begin{array}{c}\text { GDP per capita } \\
\text { (USD acc. to PPP) }\end{array}$ & $\begin{array}{c}\text { GDP acc. to PPS per capita* } \\
\text { (China }=100)\end{array}$ \\
\hline 1 & 2 & 3 & 4 & 5 \\
\hline Myanmar & 58,510 & 676,577 & $1,165.70$ & 808 \\
\hline Brunei & 397 & 5,765 & 481.80 & 808 \\
\hline
\end{tabular}




\begin{tabular}{|c|c|c|c|c|}
\hline 1 & 2 & 3 & 4 & 5 \\
\hline Philippines & 90,348 & 300,000 & $3,509.86$ & 59 \\
\hline Indonesia & 228,249 & $1,860,360$ & $3,974.89$ & 67 \\
\hline Cambodia & 14,656 & 181,035 & $1,909.50$ & 32 \\
\hline Laos & 5,763 & 236,800 & $2,406.50$ & 40 \\
\hline Malaysia & 26,993 & 330,252 & $14,215.36$ & 238 \\
\hline Singapore & 4,839 & 710 & $49,283.58$ & 827 \\
\hline Thailand & 67,386 & 513,120 & $7,702.58$ & 129 \\
\hline Vietnam & 86,211 & 331,212 & $2,784.95$ & 47 \\
\hline ASEAN & 583,651 & $4,435,830$ & $4,726.00$ & 79 \\
\hline China & $1,325,640$ & $9,596,961$ & $5,961.83$ & 100 \\
\hline India & $1,190,500$ & $3,201,446$ & 3,059 & 51 \\
\hline Japan & 127,704 & 377,930 & $34,098.78$ & 572 \\
\hline Russia & 141,800 & $17,098,242$ & $16,138.55$ & 271 \\
\hline USA & 304,060 & $9,629,091$ & $46,715.52$ & 784 \\
\hline EU - 27 & 495,900 & $4,324,782$ & $32,708.00$ & 549 \\
\hline
\end{tabular}

* approximate data, calculated approximately by comparing the amount of GDP per capita according to PPP for each country with the amount of this indicator for China.

Source: www.adb.org/statistics; ASEAN Finance and Macroeconomic Surveillance Database, www.asean.org; World Economy Outlook, IMF, April 2009; http://faostat.fao.org/.

Table 3. China's growth rate against selected world countries and regions in the period 1990-2008

\begin{tabular}{|l|c|c|c|c|c|c|c|c|}
\hline \multicolumn{1}{|c|}{ Country } & 1990 & 1995 & 1997 & 2000 & 2004 & 2006 & 2007 & 2008 \\
\hline \multicolumn{1}{|c|}{1} & 2 & 3 & 4 & 5 & 6 & 7 & 8 & 9 \\
\hline Myanmar & 2.8 & 6.9 & 5.7 & 13.7 & 13.6 & 12.7 & no data & no data \\
\hline Brunei & 1.1 & 4.5 & -1.5 & 2.8 & 0.5 & 4.4 & 0.6 & no data \\
\hline Philippines & 3.0 & 4.7 & 5.2 & 6.0 & 6.4 & 5.3 & 7.1 & 3.8 \\
\hline Indonesia & 9.0 & 8.4 & 4.7 & 4.9 & 5.0 & 5.5 & 6.3 & 6.1 \\
\hline Cambodia & no data & 6.4 & 5.6 & 8.8 & 10.3 & 10.8 & 10.2 & 6.7 \\
\hline Laos & 6.7 & 7.0 & 6.9 & 5.8 & 6.4 & 8.4 & 7.6 & 7.5 \\
\hline Malaysia & 9.0 & 9.8 & 7.3 & 8.9 & 6.8 & 5.8 & 6.3 & 4.6 \\
\hline Singapore & 9.2 & 8.2 & 8.3 & 10.1 & 9.6 & 8.4 & 7.8 & 1.1 \\
\hline Thailand & 11.2 & 9.2 & -1.4 & 4.8 & 6.3 & 5.1 & 4.9 & 2.5 \\
\hline Vietnam & 5.1 & 9.5 & 8.2 & 6.8 & 7.8 & 8.2 & 8.5 & 6.2 \\
\hline ASEAN & 7.6 & 4.1 & 4.1 & 5.9 & 6.1 & 6.0 & 6.6 & 4.4 \\
\hline China & 3.8 & 10.9 & 9.3 & 8.4 & 10.1 & 11.6 & 13.0 & 9.0 \\
\hline India & 5.5 & 7.6 & 4.1 & 4.0 & 8.3 & 9.7 & 9.1 & 6.1 \\
\hline
\end{tabular}




\begin{tabular}{|l|c|c|c|c|c|c|c|c|}
\hline & 2 & 3 & 4 & 5 & 6 & 7 & 8 & 9 \\
\hline Japan & 5.2 & 2.0 & 1.6 & 2.9 & 2.7 & 2.0 & 2.4 & -0.7 \\
\hline Russia & -3.0 & -4.1 & 1.4 & 10.0 & 7.1 & 7.7 & 8.1 & 5.6 \\
\hline USA & 1.9 & 2.5 & 4.5 & 3.7 & 3.6 & 2.8 & 2.0 & 0.4 \\
\hline EU - 27 & - & - & 2.7 & 3.9 & 2.5 & 3.2 & 3.0 & 0.5 \\
\hline World & 2.9 & 2.9 & 3.7 & 4.1 & 4.1 & 4.0 & 3.8 & 1.7 \\
\hline
\end{tabular}

Source: http://databank.worldbank.org/; http://epp.eurostat.ec.europa.eu/; ASEAN Finance and Macroeconomic Surveillance Unit Database (compiled/computed from data submission, publications and/or websites of ASEAN Member States' national statistics offices and relevant government agencies, and from the International Monetary Fund World Economic Outlook (IMF WEO) Database April 2010); http://dosfan.lib.uic.edu/.

\subsection{Trade ties}

The European Union, United States and China are the three primary powers in global trade. In 2007 China occupied the fourth place in the area of global goods exchange (in total import and export) with $7.7 \%$ share. In 2007 China was third in the group of the main exporters with $8.6 \%$ share, and the same position in the group of leading importers; its share in the global import volume accounted for $6.0 \%{ }^{10}$.

The regional geographic structure of China's foreign trade in 2007 was as follows. The primary export markets were Asia (47\%), European Union (20.5\%) and North America (21\%). In the case of import the situation was as follows - Asia (65\%), European Union (13\%), North America $(9 \%)^{11}$. Particularly great importance for the foreign trade is gained by ASEAN countries, whose share in the Chinese export increased from $4.7 \%$ in 1993 to $12.4 \%$ in 2007, and in import from $4.4 \%$ to $9.1 \%$ respectively in the same period (Table 4 ).

In 2007 the relevant turnover amounted to 90.6 bn USD, while the volume anticipated by China in 2010 will be circa 200 bn USD $^{12}$. However, this level was already exceeded in 2008, during the January - October 2008 period the turnover value amounted to 211 bn USD ${ }^{13}$. In 2008 the ASEAN countries were the fourth largest market for China, after EU, United States and Hong Kong, and the third largest import source after Japan and European Union.

Against that background, an interesting thesis is put forward by E. Oziewicz, that the ASEAN countries may become a specific link between China and India as part of a developing delivery chain, at the one side in the industrial production sector with China, and at the other side in the services sector with India. It is worth adding that eventually this could lead to the incorporation of India into the trilateral production cooperation of interbranch nature ${ }^{14}$. 
Table 4. Changes in the geographic structure of China's turnover with the largest partners in years 1990-2007 (in \%)

\begin{tabular}{|l|c|c|r|r|r|r|}
\hline \multirow{2}{*}{ Country/Region } & \multicolumn{3}{|c|}{ China's export } & \multicolumn{3}{c|}{ China's import } \\
\cline { 2 - 7 } & 1990 & 2000 & 2007 & 1990 & 2000 & 2007 \\
\hline United States & 8.5 & 20.9 & 19.5 & 12.2 & 9.9 & 7.5 \\
\hline Japan & 14.7 & 16.7 & 8.3 & 14.2 & 18.4 & 14.1 \\
\hline ASEAN & $4.7^{1}$ & 5.2 & 12.4 & $4.4^{1}$ & 3.5 & 9.1 \\
\hline EU - 25 & 10.0 & 27.7 & 20.5 & 17.0 & 10.7 & 13.0 \\
\hline Hong Kong & 43.3 & 17.9 & 15.2 & 0.2 & 0.7 & 1.1 \\
\hline South Korea & 0.7 & 4.5 & 4.6 & 0.4 & 10.3 & 11.0 \\
\hline Germany & 3.3 & 3.7 & 4.1 & 5.5 & 4.6 & 4.7 \\
\hline Singapore & 3.2 & 2.3 & 2.4 & 1.6 & 2.2 & 2.0 \\
\hline Russia & no data & 0.9 & 2.3 & 0.0 & 2.6 & 2.0 \\
\hline Other countries & $16.3^{3}$ & 0.2 & 10.7 & $48.9^{3}$ & 37.1 & 35.5 \\
\hline
\end{tabular}

${ }^{1}$ data as of 1993; in 1990 the trade turnover with ASEAN accounted for 6\% of China's foreign trade.

${ }^{2}$ EU - data concerning EU include: in 1990 and 2000 - 15 countries.

${ }^{3}$ taking into account ASEAN countries.

Source: own work based on: Key Indicators... (2008); Asian Development Bank; ASEAN Statistical Yearbook 2008, ASEAN Secretariat, Jakarta 2008, p. 82-83; ASEAN Statistical Yearbook 2003, ASEAN Secretariat, Jakarta 2003, p. 66, 70; http://ec.europa.eu/trade/creating-opportunities/bilateral-relations/statis-tics/; Brødsgaard, Hong (2009), p. 13; China's Trade... (2006), p. 39-42; Zhao (2008), p. 3.

Since the beginning of the 1990's the Chinese import has been oriented on modern technologies, while the export - on processed products. When the goods structure of China's foreign trade is looked at from the point of view of the intended use of the goods, very interesting trends can be noticed ${ }^{15}$. In 2007 the export structure was as follows: capital goods (20\%), intermediate goods (36\%), final consumer goods (25\%); while in the case of import - 17\%, 59\% and 3\%, respectively. These data show the processing nature of the Chinese economy.

The systematic growth and the changes of the substantive structure of goods turnover allow to describe the Chinese economy as one basing its growth on the open model, as part of which the substantive structure of foreign trade reflects, at the import side, development-related goals of the economy which are measurable in the increasing import of modern machines and equipment, while at the export side - in the capability of satisfying the changing needs of other economies in a cheaper and better way in comparison with the competitive bidders. The indicated regularities whose dynamics increased upon the China's joining WTO resulted in the extension of the ties with the ASEAN countries, in terms of obtaining raw materials, fuels, development of cooperation and political relationships.

China is one of the most important partners for ASEAN. A particularly rapid development of economic and trade cooperation occurred in the 21. century. The amount of trade turnover of ASEAN with China increased from 32.3 bn USD in 2000 to 178.2 bn USD in 2009. This 
means that the share of China in the total trade turnover of ASEAN in the period 2000-2009 increased from $4.3 \%$ to $11.6 \%$ respectively, that is almost trebled, and in terms of absolute values - increased six times ${ }^{16}$. China puts out economic challenges to its partners but also create a range of opportunities. China is not only a competitor for the ASEAN countries but also a huge export market with the potential number of 1.3 bn consumers. Analysts from the World Bank correctly noticed that "...the rapid growth of the Chinese import from Eastern Asia compensates for the losses of those countries on global markets, which result from a competitive pressure exerted by growing export from China"17.

The competitive pressure of the Chinese export is a serious problem for many ASEAN countries since there is a significant and increasing similarity of the export structures from those countries to their principal partners, above all to the USA. Research conducted by S. Srivastava and R. Rajan reveal that the greatest similarity of export structures occurs between China and Malaysia, in the case of final goods regarded as capital goods, e.g. data processing equipment, telecommunications equipment and electrical machines. In contrast, Thailand's export structure is similar to the Chinese one in terms of light industry products. It should be added, however, that in certain cases vertical specialisation makes ASEAN not competitors but rather manufacturers cooperating with and complementary to China ${ }^{18}$.

The analysis of the data provided an increasing deficit in trade turnover of ASEAN with China in the years 2000-2009, except the year 2001. A detailed analysis of trade turnover of China with individual ASEAN countries allows to notice that the less developed partners, i.e. Cambodia, Laos, Vietnam and Myanmar are recording permanent deficit in mutual trade, while all others (except Indonesia in 2006-2007) achieve a surplus ${ }^{19}$.

The opening of the Chinese market resulted in a rapid growth of absorption of goods from ASEAN countries, which in many fields remain competitive even in relation with the native Chinese goods since the non-payroll costs are relatively high in China.

\subsection{Capital flows}

A characteristic trend of the last years is also the capital expansion of Chinese enterprises as a consequence of trade expansion. The export volume of direct foreign investments of China to the ASEAN countries increased from $44.02 \mathrm{~m}$ USD in 2000 to circa 1.5 bn USD in 2008 (Table 5). The primary markets where Chinese FDI are located in the South-Eastern Asian countries are Singapore and Indonesia. While performing investments in individual ASEAN countries, China does not put out any political conditions to the governments of those countries 
(e.g. observing the human rights, developing democratic freedoms) ${ }^{20}$, which results in China's being perceived as a very desirable partner.

Table 5. Direct foreign investments of China in ASEAN countries in years 1990-2008 (in $\mathrm{m}$ USD)

\begin{tabular}{|l|r|r|r|r|r|r|r|}
\hline \multicolumn{1}{|c|}{ Country } & \multicolumn{1}{c|}{1995} & \multicolumn{1}{c|}{1997} & \multicolumn{1}{c|}{2000} & \multicolumn{1}{c|}{2005} & \multicolumn{1}{c|}{2006} & \multicolumn{1}{c|}{2007} & \multicolumn{1}{c|}{2008} \\
\hline Myanmar & 3.1 & 0.4 & - & 1.2 & 1.5 & 1.7 & 349.2 \\
\hline Brunei & 15.7 & 14.1 & - & 0.1 & 4.8 & 17.2 & - \\
\hline Philippines & 13.7 & 5.8 & - & -0.2 & 2.3 & -0.1 & -0.2 \\
\hline Indonesia & 5.7 & 8.0 & -2.8 & 299.5 & 123.6 & 117.2 & 380.2 \\
\hline Cambodia & - & - & - & 102.8 & 130.1 & 164.9 & 76.9 \\
\hline Laos & 1.5 & 2.7 & 9.1 & 4.5 & 5.3 & 1.7 & 42.9 \\
\hline Malaysia & 13.5 & 23.0 & -1.0 & 1.0 & -6.7 & 4.6 & 56.5 \\
\hline Singapore & 105.7 & 14.0 & -7.1 & 69.2 & 616.7 & 594.2 & 478.0 \\
\hline Thailand & 1.9 & -7.8 & 7.2 & 11.6 & 49.9 & 73.7 & 69.0 \\
\hline Vietnam & 7.2 & 28.1 & 26.4 & 48.2 & 88.7 & 251.8 & 44.6 \\
\hline ASEAN & $\mathbf{1 5 2 . 3}$ & $\mathbf{7 4 . 9}$ & $\mathbf{4 4 . 0 2}$ & $\mathbf{5 3 7 . 7}$ & $\mathbf{1 , 0 1 6 . 2}$ & $\mathbf{1 , 2 2 6 . 9}$ & $\mathbf{1 , 4 9 7 . 3}$ \\
\hline
\end{tabular}

Source: ASEAN Statistical Yearbook 2003, The ASEAN Secretariat, Jakarta 2003, p. 152; ASEAN Statistical Yearbook 2008, The ASEAN Secretariat, Jakarta 2008, p. 143.

Despite an evident increase of the Chinese FDI to the ASEAN countries a very great disproportion still occurs between the flows of those investments between both partners; the ASEAN countries have remained the dominant investor (Figure 1).

A significant factor contributing to the growing interest of China in locating direct investments in ASEAN countries, similarly to the Latin America and Africa, is the necessity to satisfy the power needs of this country. In order to maintain the economic growth at the current level China must ensure adequate supplies of power raw materials. Therefore, the directions of China's foreign policy have become consistent with the Chinese search for systematic and longterm supplies of petroleum. Thusly pursued politics leads, for example, to locating capital and establishing trade contacts with notorious countries, the so-called pariah states, such as Myanmar, which arouses political opposition of the United States and other democratic countries ${ }^{21}$.

In the 21. century selected industrial processes are re-located in Eastern Asia from the more advanced Asian economies (e.g. China, Malaysia) to neighbouring less developed countries, which promotes creating regional production networks. In addition, the involvement of those countries, i.e. Cambodia, Laos and Myanmar, increases in the process of attracting 
direct foreign investments from the region whose key sources are China, but also Malaysia, Indonesia, South Korea and Thailand.

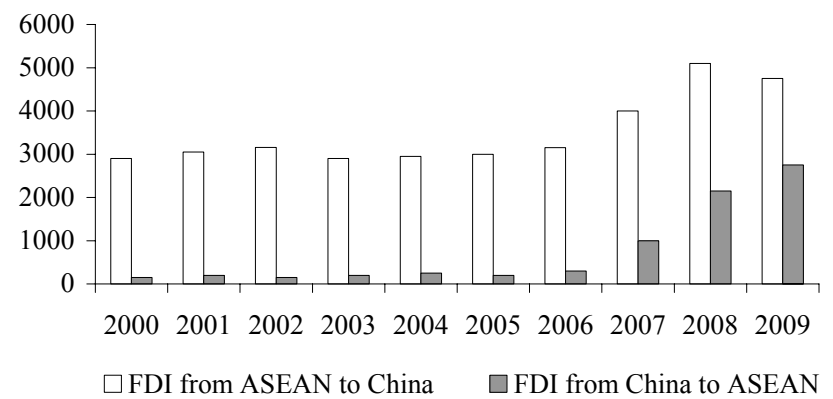

Note: in 2009 direct foreign investments from China located in the non-financial sector in the ASEAN countries amounted to 2.3 bn USD in accordance with the MOFCOM data. The total value of the Chinese FDI in the same year amounted to 2.8 bn USD in accordance with the UNCTAD estimates.

Fig. 1. Direct foreign investment flows between ASEAN and China in the period 2000-2009 (in $\mathrm{m}$ USD)

Source: World Investment Report... (2010), p. 41-42; based on UNCTAD and MOFCOM (China, Ministry of Commerce).

The sequential development concerns the selected industry branches, which is particularly noticeable in the electronics industry, where the assortment of technologically advanced products is growing, which in turn promotes specialisation. An example here is China which derives profits from the specialisation in the high-tech assortment related to the influx of FDI. The investments of the Chinese Huawei promote the growth of the telecommunications sector potential in India. Apart from the electronics, the development of regional production networks was observed in the steel and automotive sector (in Vietnam), the Chinese industry, in turn, is re-locating the textile and automotive sector to ASEAN countries, including Cambodia, Indonesia and Thailand. Along with the growth of the interregional FDI flows in industry the regionalisation of the service activity is progressing, with indication to infrastructure and finance. Chinese ICBC purchased above all Thai ACL Bank and Indonesian Halim Bank in order to handle Chinese foreign investors, as well as South Korean Taekwang Industrial investing 4.5 bn USD in a power station in Vietnam ${ }^{22}$.

The Chinese government supports direct foreign investments of native enterprises in four fields, namely:

- securing supplies of natural resources which are indispensable for maintaining the internal economic growth; 
- establishing affiliates ofChinese production enterprises and implementing infrastructural projects in which the used technology, production, equipment and manpower are exported from China;

- engaging Chinese enterprises in research and development projects which require the development of advanced technologies, management knowledge and professional skills;

- mergers and acquisitions made by enterprises from China, which allows increasing the competitiveness of native entities.

It should be noted that in 2009 China-based enterprises established 12,000 affiliates in 177 countries. In 2010, in turn, the Fortune Global 500 list enumerated 54 Chinese transnational corporations (TNC), while in 2004 there were only 16 of them. The report published by PriceWaterhoseCoopers indicates that in the years 2005-2009 the most new TNC were founded in China, and their number in the mentioned period increased from 54 to 141. Chinese TNC operate in very diverse sectors, from labour-intensive branches to technologically advanced ones, such as: production of telecommunication equipment, power, or production of green energy $^{23}$. The pursued activity arouses disquiet among their Western trade partners, who are afraid that they will lose their existing markets in the strategic industry sectors.

The expansion of TNC originating from China has been supported by information and capital since 1999 by the Chinese government, which applies a range of incentives. The following are worth mentioning: subsidies and fiscal aids for the Chinese investors, political risk insurance of the undertaken investments, concluding bilateral and regional agreements on mutual protection of investment, providing information on the investment environment on foreign markets, as well as a range of others.

The role of China in the Eastern Asia region is complex. As a result of the weakening of the position of Japan and regional newly industrialised economies as a result of the 2008-2009 crisis, the significance of China increased in the Asia restructuring and upgrading process, which is manifest in:

- increased attractiveness of China for market-oriented FDI, with reduced significance of the coastal regions for labour-intensive FDI oriented on the effectiveness due to the increase in production costs;

- increasing significance of China as the increasingly more important capital and technology supplier for less developed neighbours,

- creating and developing a new industrialisation cycle with significant implications for the development of China itself, and also its Asian neighbours. Certain industrial 
processes with relatively lower added value are transferred from the Chinese coasts to neighbouring countries, while market-oriented FDI are located in central Chinese provinces ${ }^{24}$.

The forming model of trade and capital ties between China and ASEAN countries is based to an increasingly greater extent on interregional division of labour, being both a consequence of the growing demand in Asia (particularly on the part of China), and the demand of highly developed countries ${ }^{25}$. Direct benefits for the South-Eastern Asian countries resulting from those changes consist in the increase in trade in the region, particularly in the growth of the export within Asia, which results in a change in the export structure, in which intermediate (cooperation) export plays the principal role.

\section{Implications of China's economic expansion for the ASEAN countries}

What are the implications of China's expansion for the ASEAN countries? Certain scholars suggest that the growing economic, political and military power of that country will soon drive other regional powers present in South-Eastern Asia, including the United States, out. However, it is important to keep appropriate proportions. China are gradually reinforcing the status of the regional trade leader (although they are not yet able to achieve the level of American or Japanese investments), however the growing level and dynamics of economic interactions is not necessarily translated into the political dimension.

ASEAN is interested in strengthening the trade and cooperation ties with China, but given the historical, ethnic and geopolitical aspects it still fears the long-term ambitions of China in South-Eastern Asia, in particular regarding regional hegemony. The majority of ASEAN countries sustained huge losses in the fight for independence and sovereignty, so they are very cautious and sensitive about their political autonomy.

By becoming involved in bilateral and multilateral relations with China, ASEAN countries care about the maintenance of presence of external powers in order to balance the potential of China. Since the end of the Cold War many ASEAN countries have been trying to maximise the economic ties with the United States since they are an absorptive market and source of foreign investments. Since 11 September 2001 the relations of the United States with the ASEAN countries, except Myanmar, have been stronger. Generally, the security relations connecting the United States with the ASEAN countries remain incomparable with those initiated by China.

Nevertheless, the development of trade and cooperation relations between China and ASEAN countries is a fact, and the FTA binding upon them since 1 January 2010 is very likely 
to contribute to the reinforcement of those ties in the next few or dozen years, in which both parties are interested.

\section{Notes}

1 EAS was perceived by leaders as a strategic forum supporting EAC, but it seems to have its own identity nowadays, manifest in e.g. the Japan's proposal regarding CEPEA, or power-related projects. What is significant, ASEAN +3 and EAS remain mutually complementary.

2 Asian Regional... (2004).

3 Lu (2003).

4 Kawai (2004).

5 Regional Trade Agreements... (2010).

6 ASEAN+3 summit is an informal summit of ten ASEAN countries, China, Japan and South Korea.

7 Thayer (2001).

8 Sheng (2003), p. 5-6.

9 ASEAN - China to... (2009).

${ }^{10}$ Own calculations based on: Procesy globalizacyjne... (2009), p. 66-67.

11 Starzyk (2009), p. 215.

12 Oziewicz (2007), p. 36 and subs.

${ }^{13}$ Statistical data after China Ministry... (2008).

14 Oziewicz (2007), p. 38.

${ }^{15}$ China Ministry... (2008).

${ }^{16}$ Own calculations based on data colected in article: Skulska (2010), p. 401.

17 World Bank (2006), p. 17.

${ }^{18}$ Srivastava, Rajan (2004), p. 171-204.

${ }_{19}$ Volz (2010), p. 44.

${ }^{20}$ Never too late... (2006).

${ }^{21}$ Meredith (2009), p. 272.

22 World Investment Report... (2010), p. 41-42.

${ }^{23}$ Heiduk, McCaleb (2010).

${ }^{24}$ World Investment Report... (2010), p. 41-42.

${ }^{25}$ Oziewicz (2007), p. 37.

\section{References}

“ASEAN - China to kick off” (2009). Straits Times, 31 December.

Asian Regional Governance. Crisis and Change (2004). K. Jayasuriya (ed.). Taylor \& Francis. 
Brødsgaard, K.E., Hong W.M., (2009). Eu-China relations: economics still in command?, EAI Background Brief No. 484, 15 October.

China and Asian Regionalism (2010). Zhang Yunling (ed.). World Scientific Publishing Co. Pte. Ltd., Singapore.

China Ministry of Commerce, http://english.mofcom.gov.cn/static/column/statistic/ie.html/1.

China's Trade with the United States and the World (2006). Congressional Research Service, The Library of Congress, $18^{\text {th }}$ August.

Heiduk, G., McCaleb, A., (2010). Does China Switch from it's "Invite-In-Go-Out” Strategy toward a "Block-And-Attack" Strategy?, Lecture delivered on the III international Scientific Conference „Asia-Europe. Partnership or Rivalry?”, Wroclaw University of Economics, 22 November 2010.

Kang, D.C. (2003). Getting Asia Wrong: The Reed for New Analytical Frameworks, International Security, vol. 27, No. 4, Spring.

Kawai, M. (2004). Regional Economic Integration and Cooperation in East Asia, Impact and Coherence of OECD Country Policies on Asian Developing Economies, Policy Research Institute of the Japanese Ministry of Finance / OECD, Tokyo.

Key Indicators for Asia and Pacific 2008 (2008). Asian Development Bank, Manila.

Lu, F. (2003). Free Trade Area: Awakening regionalism in East Asia, China Center for Economic Research Working Paper Series, No. E2003010, Peking.

Meredith, R. (2009). Chiny i Indie. Supermocarstwo XXI wieku. Warszawa: Media Lazar NADIR.

Never too late to scramble (2006). The Economist, $28^{\text {th }}$ October.

Oziewicz, E. (2007): Dylematy rozwoju gospodarczego krajów Azji Południowo-Wschodniej na tle procesów globalizacyjnych, Gdańsk: Wydawnictwo Uniwersytetu Gdańskiego.

Procesy globalizacyjne w gospodarce światowej. Wybrane zagadnienia, (2009). B. Skulska (ed.). Wrocław: Wyższa Szkoła Zarządzania "Edukacja”.

Regional Trade Agreements notified to the GATT/WTO and in Force (2010). WTO, http://www. wto.org.

Sheng, L. (2003). China-ASEAN Free Trade Area: Origins, Developments and Strategic Motivations, ISEAS Working Paper: International Politics \& Security Issues Series No. 1.

Skulska, B. (2010). Proces integracji gospodarczej Chin z krajami ASEAN, Studia Ekonomiczne $\mathrm{nr} 4$ (LXVII) .

Srivastava, S., Rajan, R. (2004). What does the economic rise of China imply for ASEAN and India: focus on trade and investment flows, in: Foreign investment in developing countries, H. Kehal (ed.). Houndmills: Pelgrave Macmillan. 
Starzyk, K. (2009). Zagraniczna polityka ekonomiczna Chin w procesie rynkowej transformacji gospodarki. Przypadek Chin. Warszawa: Wydawnictwo Placet.

Storey, I. (2006). China's Malacca dilemma, China Brief, vol. 6, issue 8, April 12.

Storey, I. (2007). The United States and ASEAN-China relations: all quiet on the Southeast Asian front, October, http://www.StartegicStudiesInstitute.army.mail/ (2010-09-12).

Straits Times, November 2, 2006.

Thayer, C.A. (2001). "ASEAN Ten Plus Three: An Evolving East Asian Community?”, Comparative Connections, Pacific Forum CSIS, http://www.csis.org/pacfor/cc/004Qchina _asean.html.

Volz, U. (2010). Prospects for Monetary Cooperation and Integration in East Asia, The MIT Press, Cambridge, Massachusetts, London, England.

World Bank (2006). East Asia update. November. Managing through a global downturn. Washington, DC: World Bank.

World Investment Report 2010. Investing in a low-carbon economy (2010). UNCTAD, New York and Geneva.

www.adb.org/statistics.

www.asean.org.

Zhao, J. (2008). ASEAN-China Trade Relations: 15 Years of Development and Prospects, The Gioi Publishers.

Acknowledgements: The article was prepared as a part of scientific research project N N114 380240 titled Nowy regionalizm Azji Wschodniej. Ewolucja - instytucjonalizacja - podmioty, financed by National Science Centre. 